УАК: 338.242 .2

\section{УПРАВЛІННЯ РОЗВИТКОМ ЕКОЛОГО- ЕКОНОМІЧНИХ СИСТЕМ АГРАРНОГО ПРИРОДОКОРИСТУВАННЯ В УМОВАХ ГЛОБАЛІЗАЦІї ${ }^{\circ}$}

$\mid$

\author{
ПРЯМУХІНА Н.В., \\ доктор економічних наук, професор, \\ завідувач кафедри економіки, \\ Вінницький національний \\ аграрний університет \\ (м. Вінниця)
}

Статтю присвячено підходам до управління розвитком еколого-економічних систем аграрного природокористування в умовах глобалізащії. Зазначено, щзо важливою умовою забезпечення стабільності $i$ розвитку еколого-економічної системи аграрного природокористування є інноваційний характер процесу відтворення й ефективне управління його розвитком. Перспективні підходи до формування організаційно-економічного механізму природокористування на різних рівнях управління сочіально-економічним розвитком передбачають розробку адаптивних регіональних еколого-економічних систем, щуо дозволяють планувати ц̌ розвивати сільськогосподарське виробництво з урахуванням припустимого антропогенного навантаження. Визначено специфіку еколого-економічних систем, принципи управління та послідовність прийняття рачіонального рішення щзодо формування екологоекономічної системи аграрного природокористування. Обгрунтовано доцільність формування моделі прийняття рішень, яка базується на структурованих знаннях, описі накопиченого досвіду управління аграрним виробництвом та його екологічної оцінки. Визначено концептуальні основи такої моделі та окреслено функиії, які будуть реалізовані системою адаптивного управління технологічними процесами в еколого-економічній системі аграрного природокористування.

Ключові слова: еколого-економічна система, система аграрного природокористування, глобалізація, управління розвитком, механізм природокористування, адаптивна система, модель прийняття рішень.

Рис.: 4. Літ.: 8.

\title{
DEVELOPMENT OF ECOLOGICAL AND ECONOMIC SYSTEMS OF AGRARIAN NATURE MANAGEMENT IN CONDITIONS OF GLOBALIZATION
}

\author{
PRIAMUHINA Natalia, \\ Doctor of Economic Sciences, Professor, \\ Head of the Department of Economics, \\ Vinnytsia National Agrarian University
}

The article is devoted to approaches to the development of ecological and economic systems of agrarian nature management in conditions of globalization. It is noted that an important condition for ensuring the stability and development of the ecological and economic system of agrarian nature is the innovative nature of the reproduction process and effective management of its development. Perspective approaches to the formation of organizational and economic mechanism of nature management at different levels of management of socio-economic development include development of adaptive regional ecological and economic systems that allow to plan and develop agricultural production taking into account the permissible anthropogenic load. Specifics of ecological-economic systems, principles of management and consistency of making a rational decision on formation of ecological-economic system of agrarian nature management are determined. The expediency offorming a decision making model based on structured knowledge, description of the accumulated experience of agrarian production management and its ecological assessment is substantiated. The conceptual foundations of such a model are defined and the functions that will be implemented by the system of adaptive control of technological processes in the ecological and economic system of agrarian nature management are outlined. 
Key words: ecological-economic system, agrarian nature management system, globalization, development management, nature management mechanism, adaptive system, decision making model.

Fig.: 4. Ref.: 8.

\title{
УПРАВЛЕНИЕ РАЗВИТИЕМ ЭКОЛОГО-ЭКОНОМИЧЕСКИХ СИСТЕМ АГРАРНОГО ПРИРОДОПОЛЬЗОВАНИЯ В УСЛОВИЯХ ГЛОБАЛИЗАЦИИ
}

\author{
ПРЯМУХИНА Н.В., \\ доктор экономических наук, професор, \\ заведующая кафедрой экономики, \\ Винницкий национальный аграрный университет
} (2. Винница)

Статья посвящена подходам к управлению развитием эколого-экономических систем аграрного природопользования в условиях глобализаџии. Отмечено, что важньм условием обеспечения стабильности и развития эколого-экономической системы аграрного природопользования является инновационный характер процесса воспроизводства и эффективное управление его развитием. Перспективные подходы $к$ формированию организационноэкономического механизма природопользования на различных уровнях управления сочиальноэкономическим развитием предусматривают разработку адаптивных региональных экологоэкономических систем, позволяющих планировать и развивать сельскохозяйственное производство с учётом допустимой антропогенной нагрузки. Определена специфика экологоэкономических систем, принципь управления и последовательность принятия рационального решения по формированию эколого-экономической системь аграрного природопользования. Обоснована челесообразность формирования модели принятия решений, основанная на структурированных знаниях, описании накопленного опыта управления аграрным производством и его экологической оценки. Определены концептуальные основы такой модели и обозначены функиии, которые будут реализованы системой адаптивного управления технологическими процессами в эколого-экономической системе аграрного природопользования.

Ключевые слова: эколого-экономическая система, система аграрного природопользования, глобализация, управление развитием, механизм природопользования, адаптивная система, модель принятия решений.

Рис.: 4. Лит.: 8.

Постановка проблеми. Сучасна еколого-економічна система аграрного природокористування потрапляє під вплив глобалізації, посилений наявними проблемами господарської діяльності, потерпає від обмеженості ресурсів, тому важливою умовою забезпечення ії стабільності і розвитку $\epsilon$ інноваційний характер процесу відтворення й ефективне управління його розвитком. Управління розвитком еколого-економічних систем для аграрного виробництва - це, передусім, реалізація доктрини запобігання економічному збитку навколишнього середовища, розробка й впровадження систем землеробства, заснованих на принципово нових підходах до природокористування, ресурсозбереження, біологічних прийомах підвищення родючості грунтів, які мають забезпечити розширене відтворення та корелювати з реалізацією доктрини сталого розвитку.

Такий підхід до тлумачення зазначеного питання є наслідком взаємозв’язку трьох базових складових еколого-економічної політики: зниження шкоди, досягнення комфортності проживання, екологічно стійкого розвитку. Вони визначають формування основ сучасної теорії економіки природокористування та вживлюють в екологічні цінності й економічні переваги сукупність нових знань, які торкаються різних аспектів феномену еколого-економічної системи.

Поряд із цим, недостатня увага до процесів, які відбуваються в системі аграрного природокористування, зокрема у взаємодії 3 еколого-економічною системою та супутнім ій відтворювальним процесам, актуалізує вивчення механізму управління розвитком цієї системи 3 метою забезпечення ефективного аграрного виробництва в умовах глобалізації.

Нині перспективні підходи до формування організаційно-економічного механізму природокористування на різних рівнях управління соціально-економічним розвитком передбачають розробку адаптивних регіональних еколого-економічних систем, що дозволяють планувати й розвивати сільськогосподарське виробництво 3 урахуванням припустимого антропогенного навантаження, нових організаційно-економічних принципів управління 


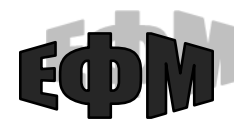

http://efm.vsau.org/

механізованими процесами на основі сучасних інформаційних технологій. Основу такого методичного підходу мають скласти принципи процесно зорієнтованого підходу до управління еколого-економічною системою на основі моделювання основних і допоміжних процесів у віртуальній системі аграрного природокористування. Тому дослідження теоретичних і практичних проблем управління розвитком еколого-економічної системи аграрного природокористування та використання інструментів регулювання нераціональної поведінки учасників економічної діяльності за умов глобалізаційних процесів є надзвичайно актуальним.

Аналіз останніх досліджень і публікацій. Різнопланові аспекти проблем параметричної оцінки природоохоронних заходів, сталого розвитку та управління еколого-економічними системами досліджувалися в роботах багатьох економістів. Економічні аспекти охорони навколишнього середовища і природокористування широко розглянуті в працях О. Голуба [1], К. Гофмана, О. Шаповалової [2], І. Красовською, В. Дешко [3], Е. Струкової, Т. Хачатурова, П. Шауера та ін. Однак недостатньо вивченими залишаються питання управління розвитком еколого-економічних систем з урахуванням раціонального природокористування, не розроблений також інструментарій для їхньої інформаційної підтримки.

Формулювання цілей статті. Метою статті $\epsilon$ формулювання напрямів удосконалення управління еколого-економічними системами аграрного природокористування, а також обгрунтування основних організаційно-економічних заходів раціонального природокористування в умовах глобалізації.

Виклад основного матеріалу дослідження. Економічне поняття «еколого-економічна система» визначається дослідниками як сукупність взаємопов'язаних економічних, технічних, соціальних і природних факторів, у процесі розвитку яких важливо акцентувати увагу на одночасному врахуванні декількох альтернативних, взаємодоповнювальних напрямів, які мають свої межі і змінюються в часі під впливом соціально-економічних умов і природно-наукових передумов їхньої реалізації [4].

3 погляду управління специфіка еколого-економічних систем полягає в наступному:

-результати діяльності керованих суб'єктів багатоаспектні (присутні, як мінімум, дві складові результатів - «економічна» і «екологічна») й схильні до впливу безлічі неконтрольованих, невизначених і випадкових чинників;

-інтереси різних керівних органів можуть не лише не збігатися з інтересами підприємств, але й суперечити один одному;

-витрати на регулярне отримання достовірної і повної інформації досить значні;

- еколого-економічні системи не можуть самостійно відстоювати свої інтереси, їхня реакція носить інертний характер і здійснюється із затримкою;

-істотними, а багато в чому і вирішальними, $є$ інституційні обмеження (нормативно-правова база) діяльності підприємств та їхня взаємодія з керівними органами.

Перераховані особливості еколого-економічних систем вимагають розробки спеціальних методів дослідження при обгрунтуванні відповідних механізмів управління агровиробничою сферою.

Визначаємо наступні принципи управління еколого-економічною системою:

- принцип дослідження обмежень і встановлення критеріїв вирішення проблеми, які дозволяють відкинути непридатні підходи і виявити альтернативи. При цьому важливо виявити реальність реалізації альтернатив, наявність і доступність ресурсів: трудових, матеріальних, фінансових, часових та ін.;

- принцип еколого-економічного управління - прагнення до забезпечення зростання добробуту суспільства і зниження екологічних збитків в аграрному природокористуванні за обов'язкової умови позитивного балансу «вигода - збиток»;

- принцип обмежень небажаних впливів заходів у сфері управління еколого-економічною системою має реалізовуватися в рамках обмежень впливу на агровиробничі системи.

Розвиток еколого-економічних систем аграрного природокористування визначається процесами, що в них відбуваються, ризиками та загрозами їхній безпеці, перспективами соціальноекономічного розвитку. Для того щоб уникнути або, принаймні, попередити загрози екологоекономічній безпеці, які генеруються структурними дисбалансами в економічній та соціальній сферах за умов глобалізації і, як наслідок, зумовлюють обмежене відтворення природних ресурсів, бажано переводити аграрне природокористування на принципи сталого розвитку. 
Вважаємо, що засади сталого розвитку, які є загальноприйнятими у Європі [5] та повинні бути виконані країнами світової спільноти, мають бути доповнені й розширені щодо екологічного складника, зокрема сутністю екологічного збитку, економічною оцінкою використання природних ресурсів галузями економіки, оцінкою забруднення навколишнього природного середовища, екологічним страхуванням тощо.

Прийняття раціонального рішення щодо формування еколого-економічної системи аграрного природокористування пропонується здійснювати за схемою (рис. 1).

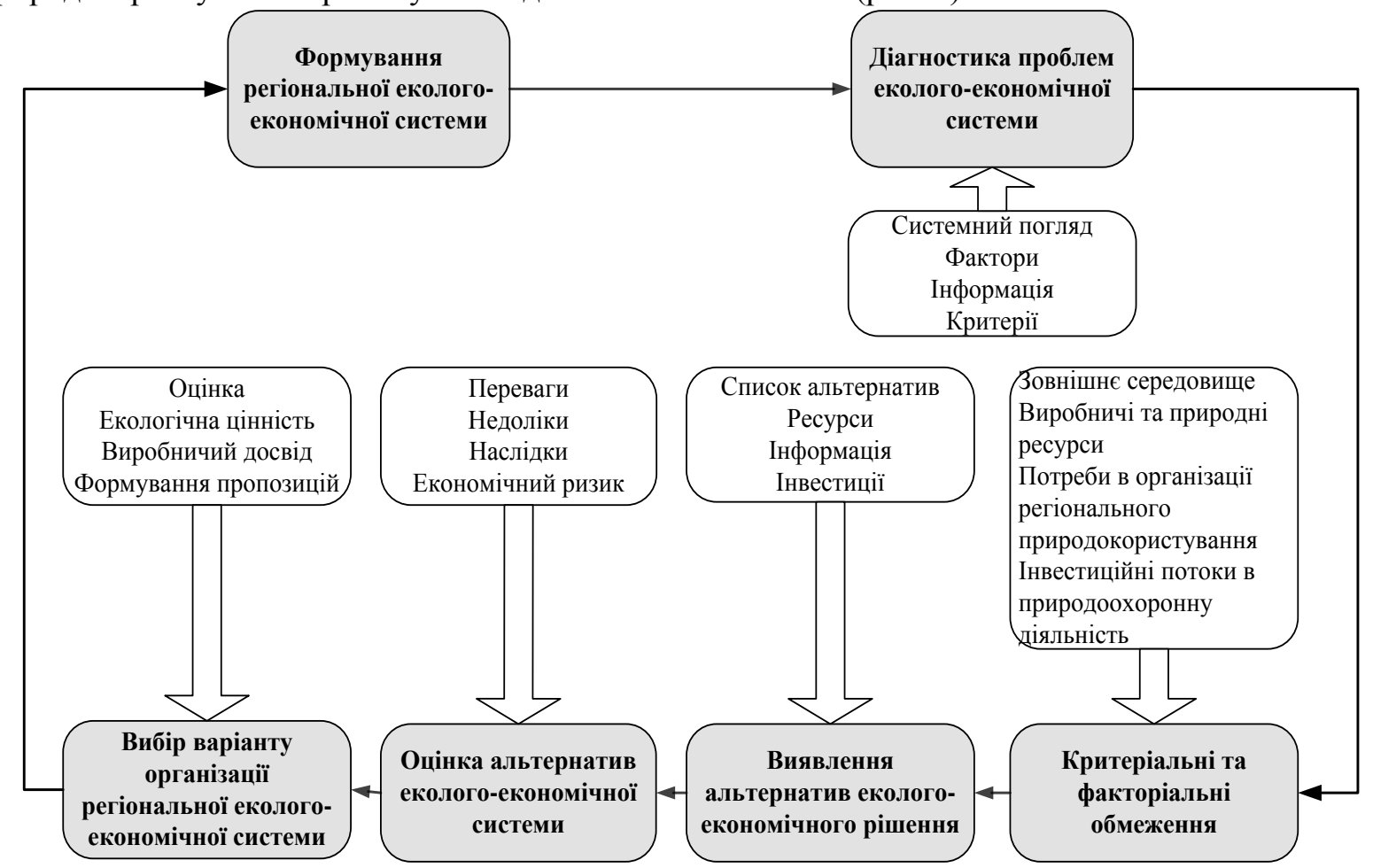

Puc. 1. Схема процесу прийняття раціонального рішення при формуванні екологоекономічної системи аграрного природокористування

Джерело: розроблено автором

Зі схеми видно, що прийняття оптимального рішення починається з діагностики проблеми $\mathrm{i}$ базується, передусім, на системному представленні об'єкта управління. Залежно від поставлених цілей, завдань і проблеми, що розглядається, обирається арсенал прийомів діагностики. Головне у діагностиці - виявити симптоми, чинники, які характеризують стан керованої системи. Необхідно визначити вектор екологічних пріоритетів розвитку еколого-економічної системи, що дозволить провести угруповання природоохоронних заходів залежно від заподіяної шкоди.

Сільське господарство представляє одну з найважливіших галузей економіки України. Наприклад, на Вінниччині у цій сфері зайнято понад 41,3 тис. осіб. Аграрним виробництвом займаються понад 2,7 тис. сільськогосподарських підприємств, 3 них 150 середніх, 2,5 тис. малих селянських (фермерських) господарств, у тому числі 2,2 тис. особистих підсобних господарств. Їх частки в обсязі валової продукції в 2017 р. склали: 62\% - сільськогосподарські організації; 12\% селянські (фермерські) господарства; 26\% - особисті підсобні господарства. У валовому регіональному продукті частка сільського господарства у 2017 р. склала $21,7 \%$ від загальної чисельності галузей, що виробляють товари та надають послуги [6].

Перспективним напрямком розвитку агросистеми регіонів $є$ розробка і впровадження адаптивно-ландшафтного системи землекористування. Геоінформаційна система (ГІС) забезпечує систематизацію, обробку, відображення і поширення координованих даних.

Використання ГІС-технологій має на меті дати оцінку екологічної ємності агроландшафтів регіону та запропонувати механізм ефективного процесно зорієнтованого управління організаційно-економічними процесами в еколого-економічних системах аграрного природокористування [7]. На думку автора, цей механізм має включати:

- організаційне забезпечення - основний і допоміжний персонал, координацію прийняття рішень із зацікавленими інститутами та організаціями, органами управління; 
http://efm.vsau.org/

- інформаційне забезпечення - інформація про наявні дані, способи їх аналітичної обробки, програмне забезпечення, графічну інформацію, доступ до баз даних, мереж моніторингу;

- науково-методичне забезпечення - методичні, нормативні матеріали, кваліфіковані експерти, науково-дослідні організації різного профілю;

- технічне забезпечення - засоби оргтехніки, транспорту, контрольне та лабораторне обладнання, обчислювальна техніка, засоби зв'язку;

- фінансове забезпечення - стійке фінансування, оплата праці та всіх видів забезпечення.

Ілюстрацією природоохоронної діяльності може бути методика формування віртуальної еколого-економічної системи, яка, окрім моделі вибору технологій економічного блоку, повинна включати в себе опис складних процесів, що відбуваються в грунті під впливом людської діяльності, зокрема, ерозійних процесів. Об'єднання таких різнорідних блоків в єдину систему представляє комплексну і складну проблему, для вирішення якої мають бути розроблені спеціальні економіко-математичні методи і моделі, сучасні інформаційні технології. На рис. 2 подано приклад побудови такої системи.

Таким чином, на вхід еколого-економічної системи з навколишнього середовища надходять керівні параметри у вигляді безлічі обмежень на аграрне виробництво і цілей, а також ресурсів. Виходи еколого-економічної системи визначаються сукупністю кінцевих продуктів, благ і послуг, які орієнтовані на задоволення потреб внутрішнього й навколишнього середовища та здійснюють на нього негативний вплив.

Застосування системного підходу до проблеми організації аграрного виробництва дозволить всебічно розглянути способи досягнення економічних цілей 3 урахуванням екологічних компонентів, а застосування новітніх інформаційних технологій - організувати введення і виведення даних, виконати аналіз великого масиву первинного матеріалу.

ЗОВНІШНС СЕРЕДОВИЩЕ

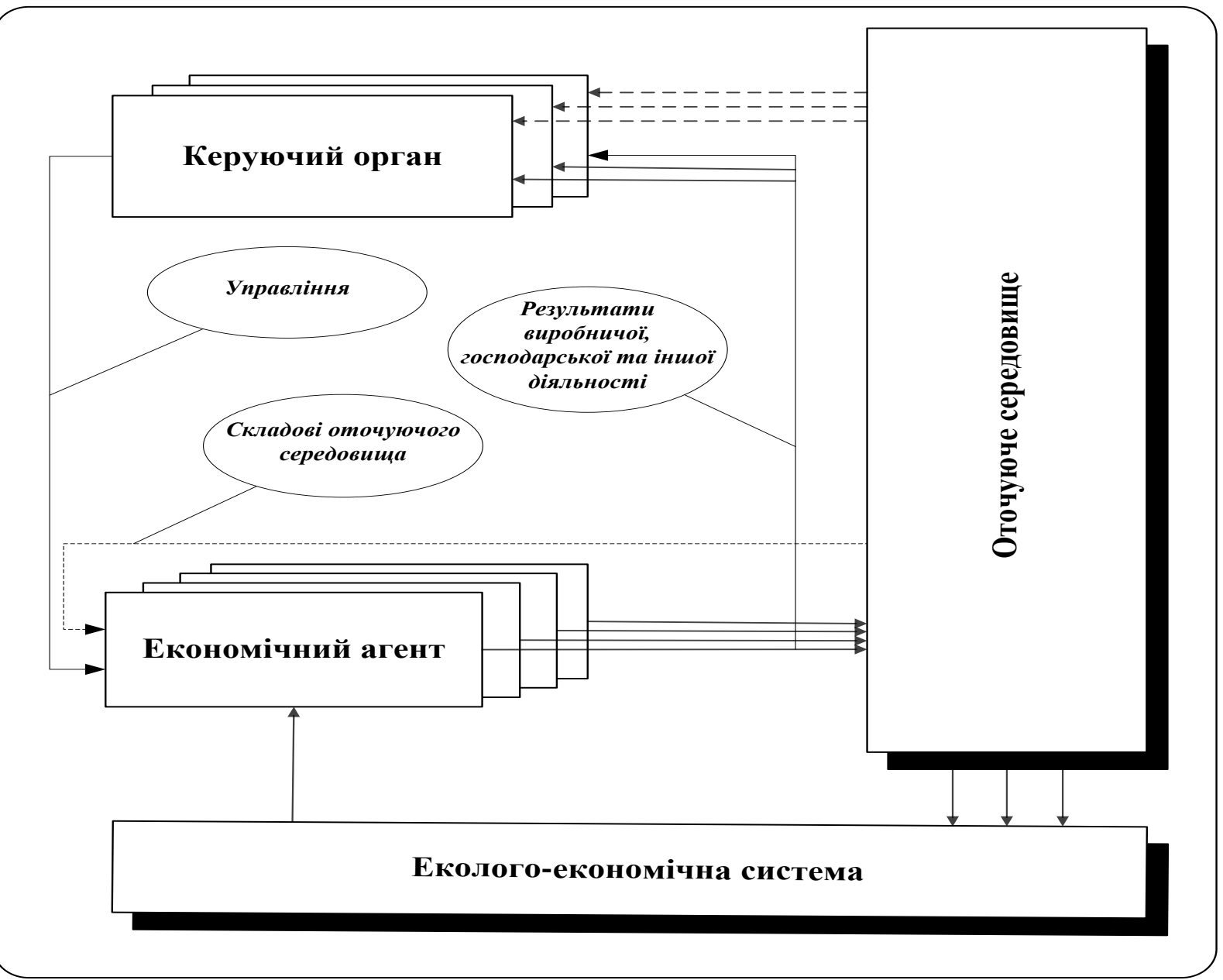

Рис. 2. Модель еколого-економічної системи аграрного виробництва

Джерело: розроблено автором 
http://efm.vsau.org/

3 огляду на складність вирішуваної проблеми, до одного з перспективних напрямів організації еколого-економічного механізму управління аграрним процесом варто віднести формування моделі прийняття рішень, що базується на знаннях, які по-суті є структурованим, формальним описом накопиченого досвіду управління аграрним виробництвом та його екологічної оцінки.

Концепція цієї моделі грунтується на зіставленні поточної інформаційної моделі екологічного середовища й аграрного процесу, іiі трансформації, з узагальненим описом припустимих еталонних ситуацій. Кожна еталонна ситуація відображає можливі припустимі умови, які можуть скластися в процесі аграрного природокористування в зовнішньому середовищі. Ці умови зіставляються з поточної метою функціонування підприємства. На основі опитування експертів обираються відповідні управлінські заходи, що забезпечують досягнення зіставленої еколого-економічної мети. Вибір управлінських рішень в цьому випадку здійснюється за результатами збігу або розбіжності порівнюваних моделей опису стану аграрних процесів відповідно до заданих на поточний момент часу цілями виробництва. Характерною особливістю концепції еколого-економічного механізму управління процесом в аграрній сфері $\epsilon$ наявність у контурі управління бази знань й підсистеми автоматизованої підтримки прийняття рішень.

На рис. 3 представлено схему управління еколого-економічною системою Вінницького регіону.

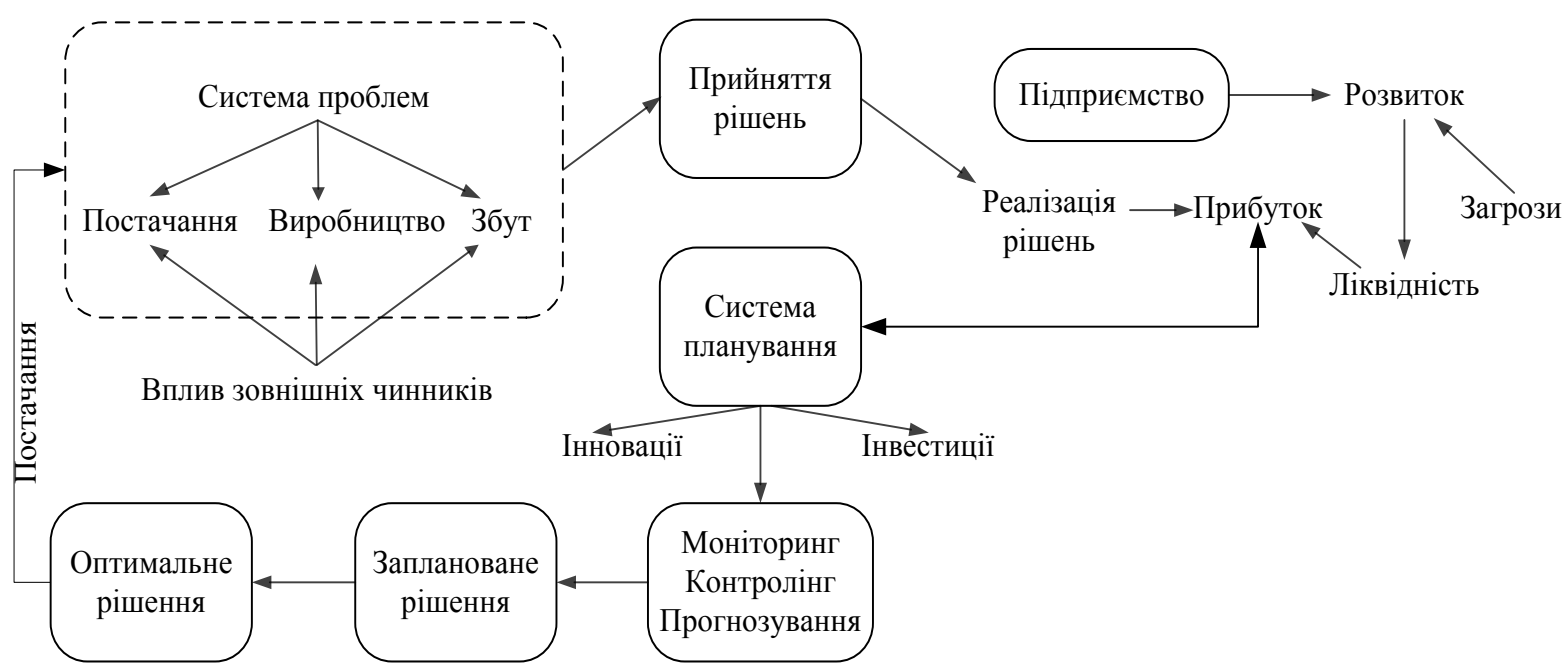

Рuc. 3. Схема управління еколого-економічною системою Вінницького регіону Джерело: розроблено автором

Зі схеми видно, що для іiі ефективного функціонування передбачені три основні блоки системи, що забезпечують:

- підготовку, прийняття та реалізацію управлінських рішень в системі (послідовне зняття невизначеності);

- процес управління підготовкою, прийняттям та реалізацією рішень (планування);

- контролінг, що забезпечує зворотний зв'язок між фактичними результатами і стратегічними цілями підприємства й процес самоналаштування структурних елементів механізму на досягнення цілей системи.

При розробці процесно зорієнтованої схеми управління варто застосувати критерії відбору програмно-цільових інструментів зниження екологічних збитків регіональними територіями, а саме:

- перехід від суто економічного обгрунтування прийняття господарських рішень із традиційними показниками собівартості, прибутку, рентабельності до багатокритеріальних рішень на основі еколого-економічної оцінки;

- еколого-економічний ефект розраховується за певний період часу на основі зіставлення результатів сільськогосподарської діяльності і витрат на виробництво сільськогосподарської продукції, збитків, завданих сільським господарством природному середовищу, а також шкоди, що відображена у недоотриманні сільськогосподарської продукції внаслідок погіршення якісних характеристик природного середовища;

- критерієм еколого-економічної ефективності сільськогосподарського виробництва $\epsilon$ максимізація розв'язку задачі щодо задоволення суспільного попиту на продукцію сільського господарства, отриману 3 оптимальними виробничими витратами за умов збереження та відтворення навколишнього середовища; 
- еколого-економічна оцінка ефективності аграрного виробництва обов'язково має враховувати різницю у часі витрат і результатів, використовуючи відому систему показників ефективності інвестиційного проекту - чистий дохід, чистий дисконтований дохід, внутрішню норму доходу;

- оцінку ефективності аграрного процесу раціонально проводити у два етапи. На першому слід визначити суспільну значимість проекту в цілому. Якщо він виявиться ефективним, то слід проводити другий етап - оцінку ефективності участі в проекті;

- для процесу аграрного природокористування, який здійснюється за рахунок власних коштів, достатньо визначити комерційну ефективність;

- роботу з оцінки та аналізу економічної ефективності слід будувати на основі спеціальної інформаційно-економічної системи планування й управління сільськогосподарським виробництвом.

Таким чином, комплексна оцінка еколого-економічної системи регіону дозволяє керівництву відслідковувати відповідність прийнятих рішень заданим стратегічним цілям регіону і виявляти «больові точки» у різних сферах діяльності. Для цього пропонується діяти відповідно до блоксхеми, наведеної на рисунку 4.

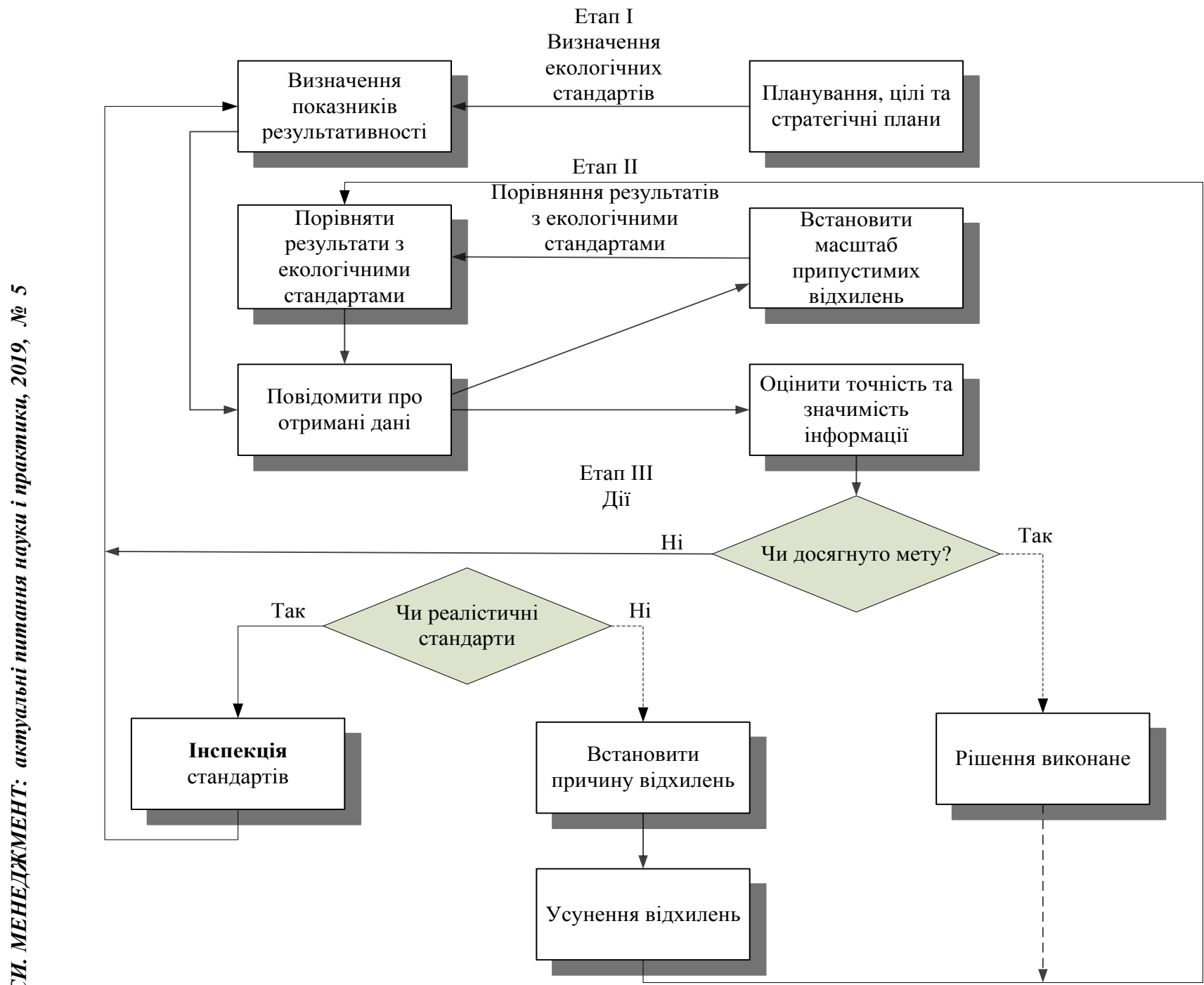

Рис. 4. Блок-схема оцінки економічної ефективності управління еколого-економічною системою

Джерело: розроблено автором

Система індикаторів стійкого розвитку визначається, виходячи 3 цілей i завдань, сформульованих на другому етапі, і відображає якісні та кількісні характеристики планованих змін в еколого-економічній системі. Заплановані зміни бажано відстежувати за трьома групами 
індикаторів: економічні, соціальні, екологічні. Планування таких змін зазвичай має на меті досягнення стабільної прогресивної тенденції до названих груп показників.

Орієнтовний перелік екологічних показників може виглядати наступним чином:

- показники рівня освоєння території: частка сільськогосподарських угідь у загальній структурі земельних ресурсів та їхня структура, розораність земель, структура і щільність поголів'я худоби;

- показники якісного стану грунтів сільськогосподарських угідь: динаміка макро- i мікроелементів в різних типах грунтів, забруднення грунтів гербіцидами, пестицидами, важкими металами та ін., оцінка деградації грунтів, що дозволяє виявити основні види, ступінь і інтенсивність деградації грантів (ущільнення, ерозія, виснаження, забруднення тощо);

- показники впливу господарства на стан і використання атмосферного повітря, водних ресурсів;

- показники використання коштів меліорації, хімізації, механізації;

- показники матеріально-технічного забезпечення і використання технологій обробітку культур, структура сівозміни;

- визначення пріоритетних напрямів сталого розвитку та ресурсної потреби.

Після того, як сформульовано цілі, встановлено індикатори, визначено пріоритетні напрямки стійкого розвитку аграрного природокористування, виникає питання, які і скільки ресурсів слід використати для досягнення запланованих індикаторів. Іншими словами, стоїть завдання визначення обсягу й структури потреб в ресурсах у планованому періоді.

Подана система адаптивного управління технологічними процесами в еколого-економічній системі аграрного природокористування дозволяє реалізувати:

- макрофункції - розробка дерева цілей системи управління, формування загальної політики поведінки системи; розробка структури системи управління та розвитку; визначення функцій та ієрархії підсистем; забезпечення цілісності системи й визначення ступеня автономності підсистем управління;

- загальні функції управління - попереднє управління (планування і прогнозування конкретних параметрів системи), оперативне управління (організація, мотивація, координація і регулювання) і кінцеве управління, або зворотний зв'язок (контроль, облік, аналіз);

- конкретні функції управління - організація робіт з планування і прогнозування, технічна підготовка виробництва, організація виробництва, оперативне управління виробництвом, організація роботи з кадрами, матеріально-технічне постачання, економічний аналіз і т. ін.;

- складні нестандартні рішення, що носять багатокритерійний характер.

Найелементарніший рівень опису такої еколого-економічної системи - це уявлення іiї у вигляді елементів сукупності будь-яких об'єктів. Причому, оскільки все розмаїття елементів множини та їхніх зв'язків неможливо або складно описати математичним рівняннями, краще розглядати його у вигляді «чорного ящика», тобто як систему 3 невідомою внутрішньою структурою та невідомою поведінкою при впливі на неї ззовні або при якихось внутрішніх змінах. Оцінити поведінку такої системи можна скориставшись методом імітаційного моделювання, що дозволяє задавати вхідні параметри впливу, подібні з реальними або бажаними впливами, а вимірюючи реакцію моделі об'єкта на них, можна вивчати його поведінку.

До групи нормативно-довідкової інформації належать: технології виробництва, характеристика технологічних операцій й алгоритми розрахунку обсягів робіт на них, характеристика використовуваних машин і машинних агрегатів, їх продуктивність, нормативна завантаження, питомі витрати палива та електроенергії, кількість і кваліфікація обслуговуючого персоналу, ставки оплати праці працівників та ін. Крім того, сюди ж відносять розрахунок біоенергетичних показників механізованих технологій.

Кінцевою метою створення та функціонування підсистеми інформаційного забезпечення $\epsilon$ підготовка значень усіх коефіцієнтів, що входять до математичної моделі оптимізації складу технічних засобів. Потім здійснюється оптимізація складу машин і формуються електронні форми вихідної техніко-економічної інформації.

Висновки. Таким чином, до числа заходів, що забезпечують управління екологоекономічними системами аграрного природокористування, варто віднести:

- діагностику проблеми, що грунтується на системному представленні об'єкта управління. Мета діагностики - виявити симптоми, чинники, які характеризують стан керованої системи; 


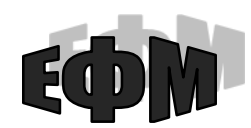

http://efm.vsau.org/

-оцінку екологічної ємності агроландшафтів регіону на основі геоінформаційної системи (ГIC), що забезпечує систематизацію, обробку, відображення і поширення координованих даних;

-методику формування віртуальної еколого-економічної системи, яка враховуючи обмеження на аграрне виробництво та ресурси, дозволяє розглянути способи досягнення економічних цілей з урахуванням екологічних компонентів;

-модель прийняття рішень, що базується на накопиченому досвіді управління аграрним виробництвом та його екологічній оцінці; зіставленні поточної інформаційної моделі екологічного середовища й аграрного процесу з узагальненим описом припустимих еталонних ситуацій;

-схему управління еколого-економічною системою конкретного регіону з урахуванням критеріїв відбору програмно-цільових інструментів зниження екологічних збитків регіональними територіями;

- систему індикаторів стійкого розвитку, що відображає якісні та кількісні характеристики планованих змін в еколого-економічній системі, які слід відстежувати за трьома групами індикаторів: економічні, соціальні, екологічні.

Послідовне використання зазначених підходів сприятиме вдосконаленню управління еколого-економічними системами аграрного природокористування, але ставить перед дослідниками нові актуальні завдання, розв'язанню яких будуть присвячені подальші дослідження.

\section{Список використаних джерел}

1. Голуб О.А. Пріоритети просторово-територіального розвитку лісового сектору України в сучасних умовах. Наиіональне господарство України: теорія та практика управління. 2009. № 44. С. 215-220.

2. Шаповалова О.М. Тенденції еколого-економічної безпеки в регіонах України. Ефективна економіка. 2014. № 2 .

3. Дешко В.І. Досвід впровадження міжнародного інвестиційного проекту з підвищення енергоефективності об’єктів соціальної сфери. Економіка і регіон. 2015. № 6. С. 59-63.

4. Похилько С.В. Сучасні еколого-економічні аспекти регіонального підходу в управлінні природокористуванням. Вісник Сумського державного університету. Серія : Економіка. 2014. № 3. С. $18-26$.

5. Вергун А.М., Тарасенко I.О. Концепція сталого розвитку в умовах глобалізації. Вісник КНУТД. Проблеми економіки організацій та управління підприємствами. 2014. №2. С. 207-218.

6. Головне управління статистики у Вінницькій області. Статистична інформація. URL: http://www.vn.ukrstat.gov.ua/index.php/statistical-information/6080-2018-06-26-11-57-18.html; URL: http://www.vn.ukrstat.gov.ua/index.php/statistical-information/6086-2018-10-23-13-36-04.html (дата звернення 10.04.2019).

7. Соловйов А.I. ГІС-технологія як інструмент управління аграрними виробничими системами. Бізнес-навігатор. 2013. № 3. С. 169-175.

8. Діброва А. Д. Сучасне трактування державного регулювання аграрного сектору економіки. Економічна теорія. — 2007. — № 1. - С. 76-84.

\section{References}

1. Holub O.A. (2009). Priorytety prostorovo-terytorial'noho rozvytku lisovoho sektoru Ukrayiny v suchasnykh umovakh [Priorities of spatial and territorial development of the forest sector of Ukraine in modern conditions]. Natsional'ne hospodarstvo Ukrayiny: teoriya ta praktyka upravlinnya - National Economy of Ukraine: Theory and Practice of Management, 44, 215-220 [in Ukrainian].

2. Shapovalova O.M. (2014). Tendentsiyi ekoloho-ekonomichnoyi bezpeky v rehionakh Ukrayiny [Trends in ecological and economic security in the regions of Ukraine]. Efektyvna ekonomika - Effective economy, 2 [in Ukrainian].

3. Deshko V.I. (2015). Dosvid vprovadzhennya mizhnarodnoho investytsiynoho proektu z pidvyshchennya enerhoefektyvnosti ob"yektiv sotsial'noyi sfery [The Experience of Implementation of the International Investment Project on Energy Efficiency Improvement in Social Sector Object]. Ekonomika i rehion - Economy and region, 6, 59-63 [in Ukrainian].

4. Pokhyl'ko S.V. (2014). Suchasni ekoloho-ekonomichni aspekty rehional'noho pidkhodu v upravlinni pryrodokorystuvannyam [The modern ecological and economic aspects of the regional approach in the management of nature use]. Visnyk Sums'koho derzhavnoho universytetu. Seriya: Ekonomika - Visnyk Sumy State University. Series: Economics, 3, 18-26 [in Ukrainian].

5. Verhun A.M., Tarasenko I.O. (2014). Kontseptsiya staloho rozvytku v umovakh hlobalizatsiyi [About the Concept of Sustainable Development in the Conditions of Globalization]. Visnyk KNUTD. Problemy ekonomiky orhanizatsiy ta upravlinnya pidpryyemstvamy - KNUTD Bulletin. Problems of enterprise economics and management, 2, 207-218 [in Ukrainian]. 
6. Statystychna informatsiya [Statistical information]. (n.d.). Holovne upravlinnya statystyky $u$ Vinnyts'kiy oblasti - The Main Department of Statistics in Vinnytsia Oblast. Retrieved from: http://www.vn.ukrstat.gov.ua/index.php/statistical-information/6080-2018-06-26-11-57-18.html

7. Solovyov A.I. (2013). HIS-tekhnolohiya yak instrument upravlinnya ahrarnymy vyrobnychymy systemamy [GIS-technology as a tool for managing agrarian production systems]. Biznes-navihator Business Navigator, 3, 169-175 [in Ukrainian].

8. Dibrova A.D. Modern interpretation of state regulation of agrarian sector of economy. Economic theory, 2007, 76-84, [in Ukrainian].

\section{Інформація про автора}

ПРЯМУХІНА Наталія Валентинівна - доктор економічних наук, професор, завідувач кафедри економіки, Вінницький національний аграрний університет (м. Вінниця, вул. Сонячна, 3 , e-mail: 877muha@gmail.com).

PRIAMUKHINA Natalia - Doctor of Economic Sciences, Professor, Head of the Department of Economics, Vinnytsia National Agrarian University (Vinnytsia, 3 Soniachna Str., e-mail: 877muha@gmail.com).

ПРЯМУХИНА Наталья Валентиновна - доктор экономических наук, професор, заведующая кафедрой экономики, Винницкий национальный аграрный университет (г. Винница, ул. Солнечная, 3, e-mail: 877muha@gmail.com).

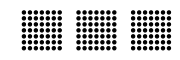

УАК: 631.16:631.147 (045)

\section{ФІНАНСУВАННЯ ОРГАНІЧНОГО АГРОВИРОБНИЦТВА В КОНТЕКСТІ ІМПАКТ-ІНВЕСТУВАННЯ ${ }^{\odot}$}

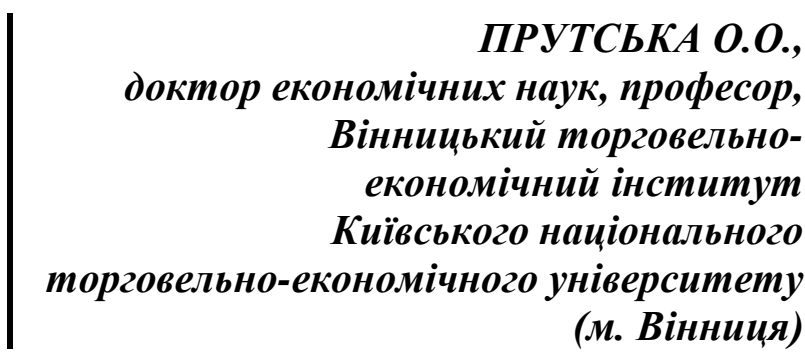

В статті розглянуто і обтрунтовано підхід до фінансування органічного виробництва як складової реалізації концепції імпакт-інвестування. Розкрито сутність, особливості та інструменти імпакт-інвестування. Обтрунтовано відмінності імпакт-інвестування від соиіального інвестування, соиіально-відповідального інвестування та соиіального підприємництва. Доведено, що імпакт-інвестування $\epsilon$ новітньою фінансовою стратегією сочіального розвитку, що передбачає інвестиції в бізнес-проекти, які від самого початку націлені на прибуток та позитивні зміни в суспільстві або довкіллі.

Обтрунтовано думку, що капіталовкладення в розвиток органічного виробництва можна розглядати як різновид імпакт-інвестування.

Зроблено висновок, що враховуючи велике сочіальне значення розвитку органічного виробництва, ті позитивні ефекти, які органічне агровиробництво потенційно може справляти на розвиток сільских територій, перспективним може бути пошук можливостей використання фінансових ресурсів агрохолдингів.

Запропоновано передбачити диференційований підхід до справляння фіксованого сільськогосподарського податку (ФСП) $з$ урахуванням наявності інвестицій в органічне агровиробництво, який спонукав би агрохолдинги передбачати в своій структурі підрозділи з органічного виробництва. Інвестиції в розвиток органічного агровиробництва, які пропонується розглядати як імпакт-інвестиції, дозволили б вітчизняним агрохолдингам певною мірою "реабілітуватися», покращити свій імідж, віддати свій борг суспільству, сприяти розвитку сільських територій. 